\title{
ARTICLE
}

\section{Fukushima radionuclides in the marine environment from coastal region of Japan to the Pacific Ocean through the end of 2016}

\author{
Michio Aoyama ${ }^{\mathrm{a}^{*}}$, Yayoi Inomata ${ }^{\mathrm{b}}$, Daisuke Tsumune $^{\mathrm{c}}$ and Yutaka Tateda ${ }^{\mathrm{c}}$ \\ anstitute of Environmental Radioactivity, Fukushima University, 1 Kanayagawa, Fukushima, 960-1296, Japan; ${ }^{b}$ Institute of Nature \\ and Environmental Technology, Kanazawa University, Kakuma, Kanazawa, 920-1192, Japan; 'Environmental Science Research \\ Laboratory, Central Research Institute of Electric Power Industry, 1646 Abiko, Abiko, 270-1194, Japan
}

\begin{abstract}
The authors present total amount of released radiocaesium from FNPP1 accident which satisfy mass balance in all components of the environment. The authors also present consensus values of Fukushima Dai-ichi Nuclear Power Plant (FNPP1) derived ${ }^{137} \mathrm{Cs}$ in the environment. Total amount of atmospheric release was 15-20 PBq and direct discharge to the ocean was 3-6 PBq, respectively. 12-15 PBq was deposited in the North Pacific and 3-6 PBq was deposited on land, respectively. Therefore 15-18 PBq was injected as sum of atmospheric deposition and direct discharge in the North Pacific Ocean. The authors also present temporal variation of ${ }^{137} \mathrm{Cs}$ in coastal region close to FNPP1 site. Based on radiocaesium activity concentration and ${ }^{134} \mathrm{Cs} /{ }^{137} \mathrm{Cs}$ activity ratios decay corrected to 11 March 2011 in surface water, major source of radiocaesium is still FNPP1 site and contribution from global fallout ${ }^{137} \mathrm{Cs}$ increased at Tomioka and Hasaki depending on the distances from FNPP1 site. A part of radiocaesium in the Sub Tropical Mode Water (STMW) in the Pacific Ocean is already obducted from ocean interior and enter into northern part of East China sea and in Japan Sea.
\end{abstract}

Keywords: Fukushima accident; radiocaesium; mass balance; inventory; North Pacific

\section{Introduction}

On 11 March 2011, an extraordinary earthquake of magnitude 9.0 centered about $130 \mathrm{~km}$ off the Pacific coast of Japan's main island, at $38.3^{\circ} \mathrm{N}, 142.4^{\circ} \mathrm{E}$, was followed by a huge tsunami with waves reaching up to $40 \mathrm{~m}$ height in Iwate region and about $10 \mathrm{~m}$ in Fukushima region [1]. These events caused the loss of about 16000 lives, missing of about 4000 lives and extensive damage. One of the consequences was a station blackout (total loss of AC electric power) at the Fukushima Dai-ichi Nuclear Power Plant (FNPP1). The station blackout developed into a disaster that left three of the six FNPP1 reactors heavily damaged and caused radionuclides to be discharged into the air and ocean [2].

Total amount of release radionuclides to the environment from the FNPP1 accident in March 2011 might be one of the big concerns about the FNPP1 accident as well as impact to human and non-human biota. In this paper, 1) we summarize total amount of released radiocaesium from the FNPP1 accident and mass balance of FNPP1 derived radiocaesium in the North Pacific Ocean and 2) present latest status of radiocaecium in the coastal region in Japan.

*Corresponding author. Email: r706@ipc.fukushima-u.ac.jp
2. Total amount of released radiocaesium from the FNPP1 accident and mass balance of FNPP1 derived radiocaesium in the North Pacific Ocean

Observed ${ }^{134} \mathrm{Cs}$ to ${ }^{137} \mathrm{Cs}$ activity ratio at the time of accident was close to $1(0.99 \pm 0.03$ in the FNPP1 north and south discharge channels) and extremely uniform [3], and ${ }^{134} \mathrm{Cs}$ to ${ }^{137} \mathrm{Cs}$ activity ratio in the estimated core inventory was also close to 1 [4], therefore in this article we assume that the total amount of ${ }^{134} \mathrm{Cs}$ released to the atmosphere and that of direct discharge to the ocean can be considered the same as the total amount of ${ }^{137} \mathrm{Cs}$ released to the atmosphere and that of direct discharge to the ocean. Total deposition of ${ }^{134} \mathrm{Cs}$ from the atmosphere on ocean surface, deposition of ${ }^{134} \mathrm{Cs}$ from the atmosphere on Japanese land and total amount of ${ }^{134} \mathrm{Cs}$ in the North Pacific Ocean also can be considered the same as those of ${ }^{137} \mathrm{Cs}$.

Estimates of the released amount of the most widely studied radionuclide, ${ }^{137} \mathrm{Cs}$, have varied from 3 to 30 $\mathrm{PBq}$ [5]. One of causes of the large variability is that most of the researchers did not consider mass balance of radiocaesium, the law of conservation of mass, in the environment. Many researchers did estimate only a part of the environment such as only to the air, only to the ocean etc. Mass balance of radiocaesium is a strong constrain to understand environmental impact of FNPP1 released radionuclides as below, 


$$
\Sigma \mathrm{R}_{i}=\Sigma \mathrm{I}_{j}
$$

where $\mathrm{R}_{i}$ are released amount to each domain and $\mathrm{I}_{j}$ are inventory in each domain and

$i$ : $1=$ atmosphere, $2=$ direct discharge

$j: 1=$ atmosphere (now zero due to short residence time), 2= land, 3=ocean, 4=sediment (known as small), 5= biota (negligible)

$$
\mathrm{R}_{1}+\mathrm{R}_{2}=\mathrm{I}_{1}+\mathrm{I}_{2}+\mathrm{I}_{3}+\mathrm{I}_{4}+\mathrm{I}_{5}=<\text { total in the core }
$$

We can also ignore $I_{1}$ due to short residence time of radionuclides in the air around a few weeks. We can ignore $\mathrm{I}_{4}$ because small amount radiocaesium in the sediment as reported to be around $130 \pm 60 \mathrm{TBq}$ $[6,7]$.We also can ignore $I_{5}$ because maximum estimate of radiocaesium in biota based on fish catch amount of $20 \times 10^{6} \mathrm{~kg}$ around Fukushima and assuming an activity of $1 \times 10^{4} \mathrm{~Bq} \mathrm{~kg}^{-1}$ give us order around GBq. Finally we can simplify the equation (2) as below;

$$
\begin{aligned}
& \mathrm{R}_{1}+\mathrm{R}_{2}=\mathrm{I}_{2}+\mathrm{I}_{3} \\
& \mathrm{R}_{1}-\mathrm{I}_{2}=\mathrm{I}_{3}-\mathrm{R}_{2}
\end{aligned}
$$

Therefore, major portion of mass balance of FNPP1 derived radiocaesium is that sum of atmospheric release and direct discharge to the ocean, $\mathrm{R}_{1}+\mathrm{R}_{2}$, must be very close to sum of inventories on land and in the ocean, $\mathrm{I}_{2}+\mathrm{I}_{3}$, as shown in Eq. (3). Tsumune et al. reported that total amount of direct discharge to the ocean, $\mathrm{R}_{2}$, was 3.5 $\pm 0.7 \mathrm{PBq}[8]$. Aoyama et al. reported based on the mass balance as shown Eqs. (3) and (4) and observed inventory in the North Pacific Ocean that atmospheric release, $\mathrm{R}_{1}$, was 15.2-20.4 $\mathrm{PBq}$ and total amount of radiocaesium deposited in the North Pacific Ocean, $\mathrm{I}_{3}-\mathrm{R}_{2}$, was 11.7-14.8 PBq [9]. Total amount of deposited radiocaesium on land, $\mathrm{I}_{2}$, was estimated to be 3.4-6.2 PBq. Finally as a total $15.2-18.3 \mathrm{PBq}, \mathrm{I}_{3}$, was estimated to be discharged to the North Pacific [9]. These discharges amount from Fukushima accident represent about $22-27 \%$ of the total input of $69 \mathrm{PBq}$ delivered to the North Pacific in the 1950s and 1960s from atmospheric nuclear weapons tests [9].

The inventory of FNPP1-released ${ }^{134} \mathrm{Cs}$ in the North Pacific Ocean, $\mathrm{I}_{3}$, was also estimated to be $15.3 \pm 2.6$ $\mathrm{PBq}[10]$ based on observational value and by Optimal Interpolation (OI) analysis which showed in good agreement with an estimate above. About half of this activity $(8.4 \pm 2.6 \mathrm{PBq})$ was found in the coastal region near the FNPP1 at the time of accident [10]. Based on a linear least-squares regression between simulated and observed ${ }^{134} \mathrm{Cs}$ activity, the total amount of ${ }^{134} \mathrm{Cs}$ injected into the North Pacific, $\mathrm{I}_{3}$, was estimated at 16.1 $\pm 1.4 \mathrm{PBq}$ [11]. This estimation also showed in good agreement with an estimate of 15.2-18.3 PBq [9] and an estimate of $15.3 \pm 2.6 \mathrm{PBq}[10]$.

In the ocean interior, radiocaesium maxima were observed at mode waters which indicate that subduction is main transport process of Fukushima derived radicaesium into the ocean interior. In the North Pacific Ocean $7.9 \pm 1.4 \mathrm{PBq}$ is in surface layer (Inomata unpublished data) and $4.2 \pm 1.1 \mathrm{PBq}$ is in Sub Tropical Mode Water (STMW) and FNPP1 derived radiocaesium was spread entire subtropical gyre in 2012 [12].

Therefore we propose consensus values of Fukushima derived radiocaseum in the environments as below combining results with other researchers.

1) $R_{1}:$ Atmospheric release: $15-20 \mathrm{PBq}[13-16]$

2) $R_{2}$ :Direct discharge: 3-6 PBq [17-19]

3) Atmospheric deposition in the North Pacific: 12-15 PBq [11]

4) $\mathrm{I}_{2}$ :Total on land: 3-6 PBq [9]

5) $\mathrm{I}_{3}:$ Total in the North Pacific Ocean: 15-18 PBq $[11,20]$

6) $\mathrm{I}_{4}: \mathrm{In}$ the sediment: $130 \pm 60 \mathrm{TBq}[6,7]$

As shown above, total amount of atmospheric release was $15-20 \mathrm{PBq}$ and direct discharge to the ocean was 3-6 PBq, respectively. 12-15 PBq, $80 \%$ of atmospheric release, was deposited in the North Pacific and 3-6 PBq was deposited on land, respectively. Therefore 15-18 PBq was injected as sum of atmospheric deposition and direct discharge in the North Pacific Ocean.

\section{Dynamics of FNPP1 derived radiocaesium}

\subsection{Sampling and methods}

We conducted enhanced surface water sampling at 84 stations in coastal regions on both the Japan Sea and Pacific Ocean sides of Japan from November 2015 to March 2016 to examine the recirculation behaviour of FNPP1-derived radiocaesium in the surface layer 5 years after the 2011 FNPP1 accident. We have also been collecting coastal water samples, basically once per month, at two coastal stations: Tomioka, Fukushima, Japan $\left(37.335^{\circ} \mathrm{N}, 141.031^{\circ} \mathrm{E}\right)$ since June 2014 and Hasaki, Ibaraki, Japan $\left(35.842^{\circ} \mathrm{N}, 140.763^{\circ} \mathrm{E}\right)$ since April 2011. Sample volumes ranged from a few litres to $10 \mathrm{~L}$, and radiocaesium in the sample seawater was extracted by an improved ammonium phosphomolybdate (AMP)/Cs compound method [21]. The AMP/Cs compound was measured by using ultra-low-background gamma-ray detectors at the Low Level Radioactivity Laboratory, Kanazawa University [22], because the total amount of ${ }^{134} \mathrm{Cs}$ in each sample was expected to be only a few $\mathrm{mBq}$ and the amount of ${ }^{137} \mathrm{Cs}$ was expected to range from a few to $20 \mathrm{mBq}$.

With this improved AMP procedure, the weight yield of $\mathrm{AMP} / \mathrm{Cs}$ compound, as well as the radiochemical yield of radiocaesium, generally exceeds $95 \%$ for less than $100 \mathrm{~L}$ samples [23]. Because the reagents used to extract radiocaesium from seawater can contain trace levels of ${ }^{134} \mathrm{Cs}$ and ${ }^{137} \mathrm{Cs}$ and we were using small-volume samples for the measurements, we needed to know the specific activity of ${ }^{134} \mathrm{Cs}$ and ${ }^{137} \mathrm{Cs}$ in the reagents. The ${ }^{137} \mathrm{Cs}$ activity in the AMP, which we synthesized ourselves, was $0.024 \mathrm{mBq} \mathrm{g}^{-1}$; thus, we subtracted from our results the expected amount of ${ }^{137} \mathrm{Cs}$ 
in the AMP used (4 to $6 \mathrm{~g}$ ) to extract radiocaesium from the samples. The ${ }^{137} \mathrm{Cs}$ activity in the $\mathrm{CsCl}$ reagent was measured as $0.03 \mathrm{mBq} \mathrm{g}^{-1}$ by extremely low background $\gamma$-spectrometry at the Ogoya underground laboratory of Low level radioactivity laboratory, Kanazawa University. We can neglect this ${ }^{137} \mathrm{Cs}$ contribution in the $\mathrm{CsCl}$ reagent because we used only $0.26 \mathrm{~g}$ of $\mathrm{CsCl}$ as a carrier for $4 \mathrm{~g}$ of AMP, or $0.39 \mathrm{~g}$ of $\mathrm{CsCl}$ as a carrier for $6 \mathrm{~g}$ of AMP. No other reagents were seriously contaminated with ${ }^{137} \mathrm{Cs}$ produced before the accident. We did not detect ${ }^{134} \mathrm{Cs}$ contamination in any of the reagents, which were produced before the FNPP1 accident.

\subsection{Temporal variation in east coast of northern Honshu Island}

Temporal variation of radiocaesium activity at Hasaki, Ibaraki, Japan, $35.842^{\circ} \mathrm{N}, 140.763^{\circ} \mathrm{E}$ is shown in Table 1 since April 2011 until June 2016. Temporal variation of radiocaesium activity at Tomioka, Fukushima, Japan, $37.335^{\circ} \mathrm{N}, 141.031^{\circ} \mathrm{E}$ is also shown in Table 2 since June 2014 until June 2016. In addition to our own data as shown in Tables 1 and 2, we compiled monitoring data from TEPCO to examine ${ }^{137} \mathrm{Cs}$ and ${ }^{134} \mathrm{Cs}$ activity trends in the surface water at the FNPP1 accident site (http://www.tepco.co.jp/nu/fukushima-np/f1/smp/2015/i mages/seawater-newest01-j.csv).

Figure 1 shows activities of ${ }^{137} \mathrm{Cs}$ in surface water at North 56 canal of FNPP1 until 26 December 2016, at Tomioka until 30 June 2016 and at Hasaki until 13 June 2016. Analyses of the ${ }^{137} \mathrm{Cs}$ activities and ${ }^{131} \mathrm{I} /{ }^{137} \mathrm{Cs}$ activity ratios suggest that the major direct release of ${ }^{137} \mathrm{Cs}$ from the FNPP1 reactors occurred during the 12 days from 26 March 2011 to 6 April 2011 (15 to 26 days after the earthquake) [24]. After that, the amount released decreased considerably although radiocaesium continued to be released about a few $\mathrm{GBq}^{-1}$ day $^{-1}$ until at least December 2016 because the ${ }^{137} \mathrm{Cs}$ activity at North 56 canal of FNPP1 still around $100 \mathrm{~Bq} \mathrm{~m}^{-3}$ (Figure 1)

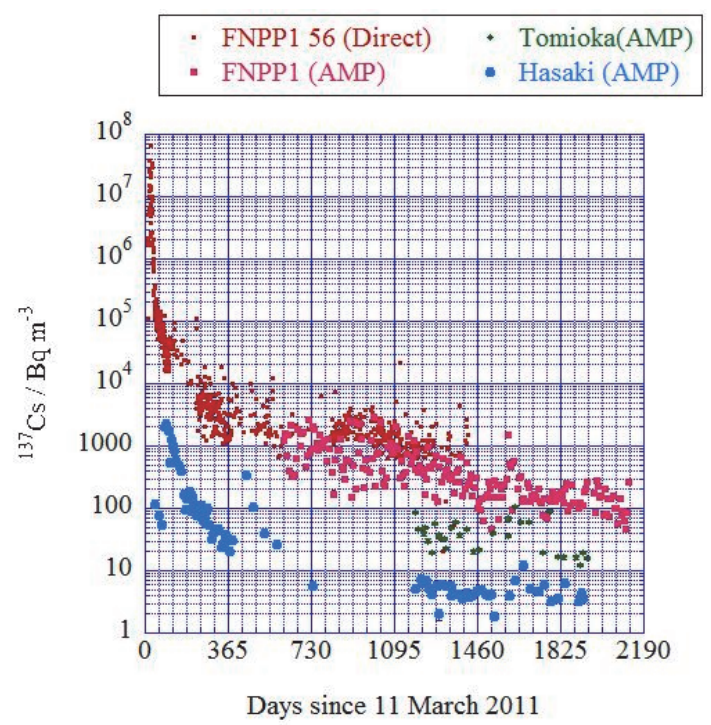

Figure 1. Activities of ${ }^{137} \mathrm{Cs}$ in surface water at North 56 canal of FNPP1, Tomioka and Hasaki. and previous coastal model simulation results [25].

The ${ }^{137} \mathrm{Cs}$ activity observed at Hasaki in 2011 ranged from $32.1 \pm 1.7$ to $2290 \pm 120 \mathrm{~Bq} \mathrm{~m}^{-3}$ and was much higher than that before the FNPP1 accident. The ${ }^{137} \mathrm{Cs}$ activity in surface water at Hasaki was $50-110 \mathrm{~Bq} \mathrm{~m}^{-3}$ until the end of May 2011 (81 days after the earthquake), and it suddenly increased to a maximum of $2080 \pm 150$ $\mathrm{Bq} \mathrm{m}^{-3}$ on 13 June 2011 (94 days after the earthquake). Then, ${ }^{137}$ Cs activity decreased steadily with an apparent half-residence time of about 21 days until the end of August 2011 (173 days after the earthquake). Subsequently, ${ }^{137} \mathrm{Cs}$ activity decreased with an apparent half-residence time of about 60 days until December 2011 (295 days after the earthquake), at which time ${ }^{137} \mathrm{Cs}$ activity in the surface water was $32-98 \mathrm{~Bq} \mathrm{~m}^{-3}$ [26]. A second increase at Hasaki occurred between 26 March and 28 May in 2012. The ${ }^{137} \mathrm{Cs}$ activity in surface water at Hasaki was $20-36 \mathrm{~Bq} \mathrm{~m}^{-3}$ from 5 March to 26 March (360 to 381 days after the earthquake), and it increased to a maximum of $347 \pm 16 \mathrm{~Bq} \mathrm{~m}^{-3}$ on 28 May 2012 (444 days after the earthquake). Then ${ }^{137} \mathrm{Cs}$ activity decreased steadily and was $5.7 \pm 0.3 \mathrm{~Bq} \mathrm{~m}^{-3}$ on 19 March 2013 (739 days after the earthquake) [26] From 9 June 2014 to 13 June 2016 (1186 to 1921 days after the earthquake), ${ }^{137} \mathrm{Cs}$ activity at Hasaki ranged from $1.9 \pm 0.1$ to $12.1 \pm$ $0.7 \mathrm{~Bq} \mathrm{~m}^{-3}$ and generally did not decreased. Comparison of the ${ }^{137} \mathrm{Cs}$ activities near the FNPP1 site and at Hasaki (Figure 1) implies that the ${ }^{137} \mathrm{Cs}$ activity observed at Hasaki might have originated from the ongoing leakage of radiocaesium from the FNPP1 site and from global ${ }^{137} \mathrm{Cs}$ fallout, and a small amount might have originated from recirculated seawater which was contaminated just after the accident.

At Tomioka, the ${ }^{137} \mathrm{Cs}$ activity in the surface water ranged from $12.5 \pm 0.7$ to $105.4 \pm 5.6 \mathrm{~Bq} \mathrm{~m}^{-3}$ from 9 June 2014 to 30 June 2016 (1186 to 1938 days after the earthquake) (Figure 1). Because Tomioka is situated between the FNPP1 site and Hasaki and the coastal current generally flows southward in this region [26], radiocaesium activities at Tomioka were between those at the FNPP1 site and those at Hasaki during the period of this study (Figure 1).

${ }^{134} \mathrm{Cs} /{ }^{137} \mathrm{Cs}$ activity ratios decay corrected to $11 \mathrm{March}$ 2011 in surface water at North 56 canal of FNPP1 close to the site were around 1 throughout the period as shown in Figure 2. And activity of ${ }^{137} \mathrm{Cs}$ in surface water at North 56 canal of FNPP1 is still highest [28]. This means that source of radiocaesium observed at North 56 canal of FNPP1 is contaminated water within the FNPP1 site. At Tomioka ${ }^{134} \mathrm{Cs} /{ }^{137} \mathrm{Cs}$ activity ratios decay corrected to 11 March 2011 in surface water ranged from $0.85 \pm 0.09$ to $1.10 \pm 0.12$ as shown Figure 2 . These activity ratios indicate that most of the radiocaesium observed at Tomioka might be originated from FNPP1 site itself. At Hasaki, ${ }^{134} \mathrm{Cs} /{ }^{137} \mathrm{Cs}$ activity ratios decay corrected to 11 March 2011 in surface water ranged from $0.81 \pm 0.07$ to $1.08 \pm 0.08$ until October 2012 , then during the period from June 2014 to June 2016 it ranged from $0.46 \pm 0.19$ to $1.10 \pm 0.12$. The contribution of global fallout ${ }^{137} \mathrm{Cs}$ to radiocaesium activity 
Table 1. Temporal variation of radiocaesium activity at Hasaki, Ibaraki, Japan, $35.842^{\circ} \mathrm{N}, 140.763^{\circ} \mathrm{E}$. Uncertainty shows one sigma of counting error plus uncertainty of calibration standard. Radioactivities in this table are decay corrected at the time of sampling.

\begin{tabular}{|c|c|c|c|c|c|c|c|}
\hline date & & $\begin{array}{l}{ }^{34} \mathrm{Cs} \\
\mathrm{q} \mathrm{m}^{-}\end{array}$ & & & $\begin{array}{l}{ }^{37} \mathrm{Cs} \\
\mathrm{q} \mathrm{m}\end{array}$ & & data sources \\
\hline 20110425 & 107 & \pm & 8 & 114 & \pm & 6 & $\mathrm{a}$ \\
\hline 20110509 & 66 & \pm & 5 & 77 & \pm & 4 & $\mathrm{a}$ \\
\hline 20110523 & 41 & \pm & 3 & 54 & \pm & 3 & $\mathrm{a}$ \\
\hline 20110606 & 1880 & \pm & 130 & 2020 & \pm & 130 & $\mathrm{a}$ \\
\hline 20110613 & 2080 & \pm & 150 & 2290 & \pm & 120 & $\mathrm{a}$ \\
\hline 20110620 & 1590 & \pm & 110 & 1760 & \pm & 90 & $\mathrm{a}$ \\
\hline 20110627 & 447 & \pm & 35 & 537 & \pm & 30 & $\mathrm{a}$ \\
\hline 20110704 & 1120 & \pm & 70 & 1290 & \pm & 70 & $\mathrm{a}$ \\
\hline 20110711 & 935 & \pm & 65 & 1070 & \pm & 60 & $\mathrm{a}$ \\
\hline 20110718 & 709 & \pm & 47 & 844 & \pm & 43 & $\mathrm{a}$ \\
\hline 20110725 & 494 & \pm & 37 & 588 & \pm & 32 & $\mathrm{a}$ \\
\hline 20110801 & 468 & \pm & 31 & 541 & \pm & 27 & $\mathrm{a}$ \\
\hline 20110808 & 397 & \pm & 32 & 455 & \pm & 26 & $\mathrm{a}$ \\
\hline 20110815 & 323 & \pm & 21 & 402 & \pm & 20 & $\mathrm{a}$ \\
\hline 20110922 & 147 & \pm & 11 & 186 & \pm & 10 & $\mathrm{a}$ \\
\hline 20110829 & 132 & \pm & 9 & 163 & \pm & 9 & $\mathrm{a}$ \\
\hline 20110905 & 74 & \pm & 6 & 93.6 & \pm & 5.1 & $\mathrm{a}$ \\
\hline 20110912 & 114 & \pm & 8 & 143 & \pm & 8 & $\mathrm{a}$ \\
\hline 20110922 & 147 & \pm & 11 & 186 & \pm & 10 & $\mathrm{a}$ \\
\hline 20110926 & 71 & \pm & 5 & 90.0 & \pm & 4.9 & $\mathrm{a}$ \\
\hline 20111003 & 138 & \pm & 7 & 155 & \pm & 7 & $\mathrm{~b}$ \\
\hline 20111010 & 102 & \pm & 7 & 126 & \pm & 7 & $\mathrm{a}$ \\
\hline 20111017 & 80.4 & \pm & 4.6 & 90.1 & \pm & 4.6 & $\mathrm{~b}$ \\
\hline 20111024 & 58.0 & \pm & 4.0 & 76.3 & \pm & 4.2 & $\mathrm{a}$ \\
\hline 20111031 & 91.9 & \pm & 5.0 & 105 & \pm & 5 & $\mathrm{~b}$ \\
\hline 20111101 & 89.3 & \pm & 50.3 & 101 & \pm & 5 & $\mathrm{~b}$ \\
\hline 20111107 & 50.6 & \pm & 4.0 & 73.6 & \pm & 4.1 & $\mathrm{a}$ \\
\hline 20111114 & 93.7 & \pm & 5.2 & 113 & \pm & 6 & $\mathrm{~b}$ \\
\hline 20111121 & 46.0 & \pm & 3.0 & 63.4 & \pm & 3.4 & $\mathrm{a}$ \\
\hline 20111128 & 65.8 & \pm & 3.6 & 76.1 & \pm & 3.7 & $\mathrm{~b}$ \\
\hline 20111205 & 43.3 & \pm & 3.5 & 55.8 & \pm & 3.2 & $\mathrm{a}$ \\
\hline 20111212 & 82.5 & \pm & 4.6 & 98.1 & \pm & 4.9 & $\mathrm{~b}$ \\
\hline 20111219 & 41.4 & \pm & 2.9 & 54.6 & \pm & 2.9 & $\mathrm{~b}$ \\
\hline 20111226 & 25.0 & \pm & 1.7 & 32.1 & \pm & 1.7 & $\mathrm{~b}$ \\
\hline 20120103 & 27.9 & \pm & 2.1 & 40.8 & \pm & 2.2 & $\mathrm{~b}$ \\
\hline 20120110 & 31.5 & \pm & 2.4 & 41.5 & \pm & 2.3 & $\mathrm{~b}$ \\
\hline 20120116 & 32.6 & \pm & 2.4 & 47.5 & \pm & 2.5 & $\mathrm{~b}$ \\
\hline 20120123 & 31.7 & \pm & 2.3 & 45.1 & \pm & 2.4 & $\mathrm{~b}$ \\
\hline 20120130 & 32.0 & \pm & 2.3 & 46.1 & \pm & 2.5 & $\mathrm{~b}$ \\
\hline 20120206 & 15.8 & \pm & 1.1 & 23.8 & \pm & 1.3 & $\mathrm{~b}$ \\
\hline 20120213 & 16.7 & \pm & 1.4 & 26.0 & \pm & 1.5 & $\mathrm{~b}$ \\
\hline 2010220 & 17.7 & \pm & 1.3 & 27.7 & \pm & 1.4 & $\mathrm{~b}$ \\
\hline 20120227 & 25.2 & \pm & 2.0 & 38.5 & \pm & 2.1 & $\mathrm{~b}$ \\
\hline
\end{tabular}

\begin{tabular}{|c|c|c|c|c|c|}
\hline \multirow{2}{*}{ date } & \multicolumn{2}{|c|}{${ }^{134} \mathrm{Cs}$} & \multicolumn{2}{|c|}{${ }^{137} \mathrm{Cs}$} & \multirow[t]{2}{*}{ data sources } \\
\hline & \multicolumn{2}{|c|}{$\mathrm{Bq} \mathrm{m}^{-3}$} & \multicolumn{2}{|c|}{$\mathrm{Bq} \mathrm{m}^{-3}$} & \\
\hline 20120305 & 26.7 & $\pm \quad 2.0$ & 36.2 & \pm 2.0 & $\mathrm{~b}$ \\
\hline 20120312 & 22.3 & $\pm \quad 1.6$ & 32.0 & $\pm \quad 1.7$ & b \\
\hline 20120319 & 11.7 & $\pm \quad 1.1$ & 20.1 & $\pm \quad 1.2$ & b \\
\hline 20120326 & 19.6 & $\pm \quad 1.4$ & 31.6 & $\pm \quad 1.7$ & b \\
\hline 20120528 & 246 & \pm 13 & 347 & \pm 16 & b \\
\hline 20120625 & 75.6 & $\pm \quad 4.2$ & 107 & \pm 5 & b \\
\hline 20120813 & 26.0 & $\pm \quad 1.7$ & 40.0 & $\pm \quad 3.0$ & b \\
\hline 20121009 & 18.3 & $\pm \quad 1.4$ & 26.3 & \pm 1.4 & $\mathrm{~b}$ \\
\hline 20130319 & 2.9 & \pm 0.3 & 5.7 & $\pm \quad 0.3$ & $\mathrm{~b}$ \\
\hline 20140609 & 1.4 & $\pm \quad 0.2$ & 5.1 & $\pm \quad 0.3$ & $\mathrm{~b}$ \\
\hline 20140623 & 2.1 & \pm 0.3 & 7.4 & $\pm \quad 0.4$ & b \\
\hline 20140714 & 1.7 & \pm 0.2 & 6.4 & \pm 0.4 & $\mathrm{~b}$ \\
\hline 20140728 & 1.9 & $\pm \quad 0.2$ & 6.9 & $\pm \quad 0.4$ & $\mathrm{~b}$ \\
\hline 20140824 & 1.4 & $\pm \quad 0.3$ & 4.2 & \pm 0.3 & $\mathrm{~b}$ \\
\hline 20140922 & ND & $\pm \mathrm{NA}$ & 2.0 & $\pm \quad 0.4$ & $\mathrm{~b}$ \\
\hline 20141005 & 1.5 & $\pm \quad 0.2$ & 5.9 & \pm 0.3 & $\mathrm{~b}$ \\
\hline 20141104 & 1.5 & $\pm \quad 0.2$ & 5.8 & $\pm \quad 0.4$ & $\mathrm{~b}$ \\
\hline 20141116 & 1.2 & $\pm \quad 0.2$ & 5.6 & \pm 0.3 & $\mathrm{~b}$ \\
\hline 20141214 & 0.5 & $\pm \quad 0.2$ & 3.6 & $\pm \quad 0.2$ & $\mathrm{~b}$ \\
\hline 20150119 & 0.7 & \pm 0.2 & 4.5 & \pm 0.3 & $\mathrm{~b}$ \\
\hline 20150202 & 1.0 & $\pm \quad 0.2$ & 3.7 & \pm 0.3 & $\mathrm{~b}$ \\
\hline 20150216 & 0.9 & \pm 0.2 & 3.9 & \pm 0.3 & $\mathrm{~b}$ \\
\hline 20150302 & 1.0 & $\pm \quad 0.2$ & 4.7 & $\pm \quad 0.3$ & $\mathrm{~b}$ \\
\hline 20150316 & 1.1 & \pm 0.2 & 4.9 & \pm 0.3 & $\mathrm{c}$ \\
\hline 20150330 & 1.0 & \pm 0.2 & 4.9 & \pm 0.3 & $\mathrm{c}$ \\
\hline 20150413 & 0.8 & \pm 0.3 & 4.1 & \pm 0.3 & $\mathrm{c}$ \\
\hline 20150427 & 0.7 & $\pm \quad 0.2$ & 4.0 & $\pm \quad 0.3$ & $\mathrm{c}$ \\
\hline 20150511 & 0.9 & \pm 0.2 & 4.2 & \pm 0.3 & $\mathrm{c}$ \\
\hline 20150525 & 0.4 & \pm 0.1 & 1.9 & \pm 0.1 & $\mathrm{c}$ \\
\hline 20150727 & 0.5 & \pm 0.2 & 4.0 & \pm 0.3 & $\mathrm{c}$ \\
\hline 20150824 & 1.8 & $\pm \quad 0.2$ & 7.1 & $\pm \quad 0.4$ & $\mathrm{c}$ \\
\hline 20150928 & 3.3 & $\pm \quad 0.4$ & 12.1 & $\pm \quad 0.7$ & $\mathrm{c}$ \\
\hline 20151026 & 0.9 & $\pm \quad 0.2$ & 5.1 & \pm 0.3 & $\mathrm{c}$ \\
\hline 20151130 & 0.7 & \pm 0.1 & 4.6 & \pm 0.3 & $\mathrm{c}$ \\
\hline 20151228 & 1.0 & $\pm \quad 0.2$ & 6.0 & $\pm \quad 0.3$ & $\mathrm{c}$ \\
\hline 20160125 & 0.8 & $\pm \quad 0.1$ & 3.3 & $\pm \quad 0.2$ & $\mathrm{c}$ \\
\hline 20160229 & 0.5 & \pm 0.1 & 3.6 & \pm 0.2 & $\mathrm{c}$ \\
\hline 20160328 & 1.1 & $\pm \quad 0.1$ & 6.3 & $\pm \quad 0.4$ & $\mathrm{c}$ \\
\hline 20160530 & 0.5 & $\pm \quad 0.1$ & 3.3 & $\pm \quad 0.2$ & $\mathrm{c}$ \\
\hline 20160606 & 0.7 & $\pm \quad 0.1$ & 4.4 & \pm 0.3 & $\mathrm{c}$ \\
\hline 20160613 & 0.5 & $\pm \quad 0.1$ & 3.6 & $\pm \quad 0.2$ & $\mathrm{c}$ \\
\hline
\end{tabular}

Table 2. Temporal variation of radiocaesium activity at Tomioka, Fukushima, Japan, $37.335^{\circ} \mathrm{N}, 141.031^{\circ} \mathrm{E}$. Uncertainty shows one sigma of counting error plus uncertainty of calibration standard. Radioactivities in this table are decay corrected at the time of sampling.

\begin{tabular}{cllllcll}
\hline Date & \multicolumn{3}{c}{${ }^{134} \mathrm{Cs}$} & \multicolumn{3}{c}{${ }^{137} \mathrm{Cs}$} & data sources \\
& \multicolumn{3}{c}{$\mathrm{Bq} \mathrm{m}^{-3}$} & \multicolumn{3}{c}{$\mathrm{Bq} \mathrm{m}^{-3}$} & \\
\hline 20140610 & 30.8 & \pm & 2.1 & 87.8 & \pm & 4.6 & $\mathrm{a}$ \\
20140623 & 14.6 & \pm & 1.2 & 45.7 & \pm & 2.4 & $\mathrm{a}$ \\
20140714 & 12.6 & \pm & 1.1 & 39.0 & \pm & 2.1 & $\mathrm{a}$ \\
20140722 & 16.9 & \pm & 1.3 & 48.5 & \pm & 2.6 & $\mathrm{a}$ \\
20140806 & 10.0 & \pm & 1.0 & 30.1 & \pm & 1.7 & $\mathrm{a}$ \\
20140821 & 6.7 & \pm & 0.6 & 19.5 & \pm & 1.1 & $\mathrm{a}$ \\
20140902 & 17.4 & \pm & 1.6 & 55.9 & \pm & 3.0 & $\mathrm{a}$ \\
20140918 & 12.4 & \pm & 1.9 & 37.0 & \pm & 2.7 & $\mathrm{a}$ \\
20140918 & 11.8 & \pm & 1.2 & 34.4 & \pm & 1.9 & $\mathrm{a}$ \\
20141003 & 10.2 & \pm & 1.0 & 32.2 & \pm & 1.8 & $\mathrm{a}$ \\
20141013 & 11.3 & \pm & 1.1 & 32.9 & \pm & 1.8 & $\mathrm{a}$ \\
20141021 & 6.5 & \pm & 0.6 & 22.7 & \pm & 1.2 & $\mathrm{a}$ \\
20141112 & 13.2 & \pm & 1.2 & 48.8 & \pm & 2.6 & $\mathrm{a}$ \\
20141202 & 19.4 & \pm & 1.6 & 61.0 & \pm & 3.2 & $\mathrm{a}$ \\
20141224 & 9.9 & \pm & 1.0 & 37.0 & \pm & 2.0 & $\mathrm{a}$ \\
20150119 & 12.7 & \pm & 1.1 & 46.9 & \pm & 2.5 & $\mathrm{a}$ \\
20150217 & 9.3 & \pm & 0.9 & 20.2 & \pm & 1.2 & $\mathrm{a}$ \\
20150317 & 6.2 & \pm & 0.6 & 21.9 & \pm & 1.2 & $\mathrm{a}$
\end{tabular}

\begin{tabular}{cllllcll}
\hline Date & \multicolumn{3}{c}{${ }^{134} \mathrm{Cs}$} & \multicolumn{3}{c}{${ }^{137} \mathrm{Cs}$} & data sources \\
& \multicolumn{3}{c}{$\mathrm{Bq} \mathrm{m}^{-3}$} & \multicolumn{3}{c}{$\mathrm{Bq} \mathrm{m}^{-3}$} & \\
\hline 20150519 & 10.2 & \pm & 1.1 & 40.0 & \pm & 2.2 & $\mathrm{~b}$ \\
20150724 & 7.8 & \pm & 0.7 & 35.3 & \pm & 1.9 & $\mathrm{~b}$ \\
20150724 & 18.5 & \pm & 1.4 & 68.7 & \pm & 3.6 & $\mathrm{~b}$ \\
20150724 & 17.8 & \pm & 1.8 & 67.9 & \pm & 3.8 & $\mathrm{~b}$ \\
20150824 & 25.4 & \pm & 2.2 & 105.4 & \pm & 5.6 & $\mathrm{~b}$ \\
20150915 & 16.2 & \pm & 1.6 & 60.4 & \pm & 3.3 & $\mathrm{~b}$ \\
20151020 & 14.3 & \pm & 1.2 & 60.5 & \pm & 3.2 & $\mathrm{~b}$ \\
20151222 & 3.7 & \pm & 0.4 & 19.4 & \pm & 1.1 & $\mathrm{~b}$ \\
20160119 & 18.1 & \pm & 1.5 & 89.1 & \pm & 4.7 & $\mathrm{~b}$ \\
20160224 & 3.4 & \pm & 0.4 & 16.9 & \pm & 0.9 & $\mathrm{~b}$ \\
20160324 & 3.0 & \pm & 0.4 & 16.4 & \pm & 0.9 & $\mathrm{~b}$ \\
20160516 & 2.9 & \pm & 0.3 & 16.3 & \pm & 0.9 & $\mathrm{~b}$ \\
20160602 & 2.3 & \pm & 0.3 & 12.5 & \pm & 0.7 & $\mathrm{~b}$ \\
20160614 & 3.3 & \pm & 0.4 & 19.3 & \pm & 1.1 & $\mathrm{~b}$ \\
20160630 & 3.1 & \pm & 0.4 & 16.0 & \pm & 0.9 & $\mathrm{~b}$ \\
\hline
\end{tabular}

a: Aoyama et al., 2016 [27].

b: This study. 
observed at Hasaki varied much during the period from June 2014 to June 2016 due to change of coastal current [26].

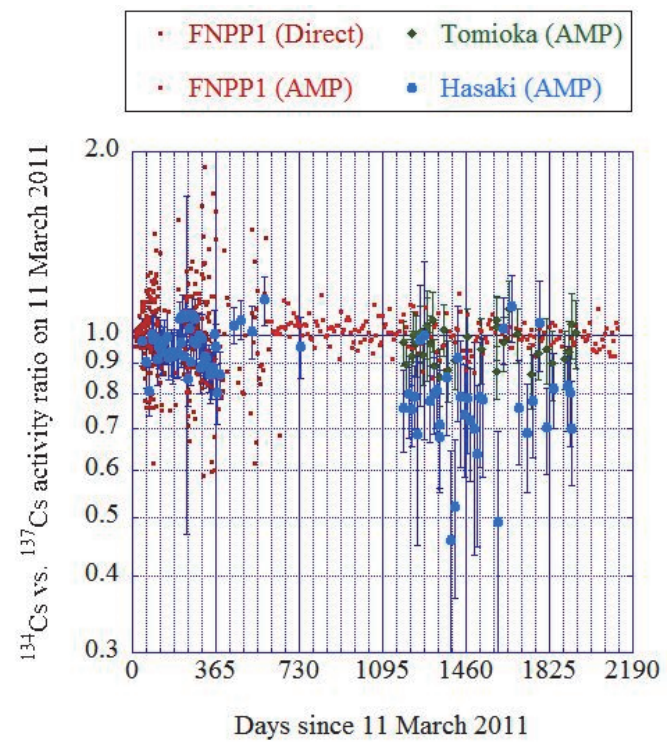

Figure 2. ${ }^{134} \mathrm{Cs} /{ }^{137} \mathrm{Cs}$ activity ratio in surface water at North 56 canal of FNPP1, Tomioka and Hasaki. Activity ratio was decay corrected to 11 March 2011.

\subsection{Eastward surface transport}

From the end of March to early April 2011, extremely high activities were observed in the coastal surface seawater near the FNPP1. The high activities spread to a region near $165^{\circ} \mathrm{E}$ in the western North Pacific Ocean, with a latitudinal center of $40^{\circ} \mathrm{N}$. Atmospheric deposition also caused high activities in the region between $180^{\circ}$ and $130^{\circ} \mathrm{W}$ in the North Pacific Ocean [10].

In summer 2012, the radiocaesium derived from the Fukushima Dai-ichi Nuclear Power Plant accident in March 2011 was found in the Bering Sea and western North Pacific between $25^{\circ} \mathrm{N}$ and $63^{\circ} \mathrm{N}$, which agrees with model simulation results of atmospheric deposition. A semi-synoptic view suggests that a main body of radiocaesium discharged directly had been transported eastward to $170^{\circ} \mathrm{W}$, northward to $50^{\circ} \mathrm{N}$, and southward to $30^{\circ} \mathrm{N}$ by summer 2012 , about one and half years after the accident [29]. The eastward speed was estimated to be $7 \mathrm{~km}$ day $^{-1}[30]$.

\subsection{Re-circulation}

A part of radiocaesium in the STMW is already obducted from ocean interior and re-circulated [28].

${ }^{137} \mathrm{Cs}$ activities in surface water during the period from Nov. 2015 to May 2016 are shown in Figure 3. Higher ${ }^{137} \mathrm{Cs}$ activities in surface water ranged from 2.0 to 2.2 $\mathrm{Bq} \mathrm{m}^{-3}$ were observed in the northern part of East China Sea, west of Kyushu Islands and Tsushima straight. On the other hands, ${ }^{137} \mathrm{Cs}$ activities in surface water in the southern part of the East China Sea were relatively low compared with those in the northern part of East China
Sea and ranged from 1.2 to $1.8 \mathrm{~Bq} \mathrm{~m}^{-3}$. This indicate that a source of relatively higher ${ }^{137} \mathrm{Cs}$ activities in surface water observed during the period from Nov. 2015 to May 2016 might be ocean interior in the Pacific side and obducted seawater of which ${ }^{137} \mathrm{Cs}$ activities are relatively high in the STMW [12-31] rather than surface water.

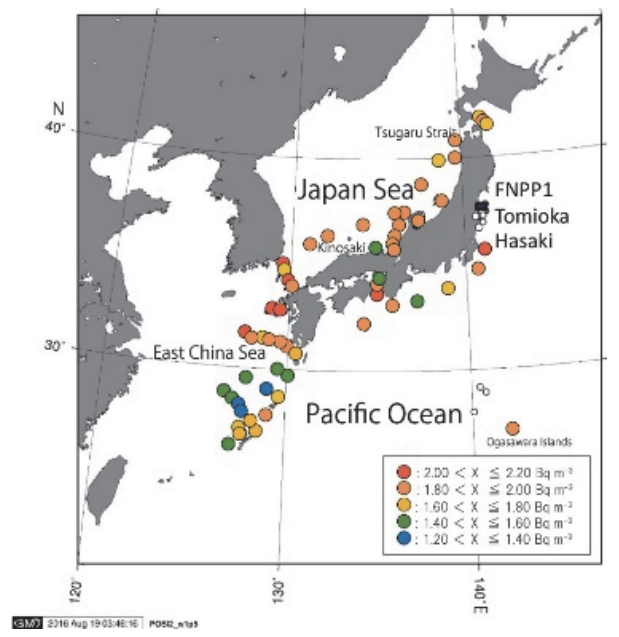

Figure 3. ${ }^{137} \mathrm{Cs}$ activities in surface water during the period from Nov. 2015 to May 2016.

\section{Conclusion}

Total amount of release of radiocaesium in each domain were reliably determined as consensus by our results and combining many researchers results as $15-20$ $\mathrm{PBq}$ for atmospheric release, 3-6 $\mathrm{PBq}$ for direct discharge to the ocean, respectively. 12-15 $\mathrm{PBq}$ was deposited in the North Pacific and 3-6 PBq was deposited on land, respectively. Therefore 15-18 PBq was injected as sum of atmospheric deposition and direct discharge in the North Pacific Ocean. These values well satisfied the mass balance of Fukushima derived radiocaesium in the environment.

In the coastal region close to FNPP1 site, based on radiocaesium activity and ${ }^{134} \mathrm{Cs} /{ }^{137} \mathrm{Cs}$ activity ratios decay corrected to 11 March 2011 in surface water revealed that major source of radiocaesium is still FNPP1 site and contribution from global fallout ${ }^{137} \mathrm{Cs}$ increased at Tomioka and Hasaki depending on the distances from FNPP1 site.

A part of radiocaesium in the STMW in the Pacific Ocean is already obducted from ocean interior and enter into northern part of East China sea re-circulated in Japan Sea.

\section{Acknowledgements}

The authors wish to thank Dr. Hamajima for his work at underground laboratory at Ogoya. We thank Kenji Watanabe and Jyunko Inomata for their work to collect seawater samples at Tomioka and Satoshi Nakamura for his kind collaboration to collect seawater samples at the research pier of Hazaki Oceanographical Research Station of the Port and Airport Research Institute. 
The authors thank for collection of seawater samples by Miyuki Takahashi at Oga Aquarium, Akita, Japan, a staff at Kinosaki Aquarium, Hyogo, Japan, Hajime Chiba at Toyama Kosen, Toyama, Japan, Shigenobu Takeda and the Captain and crew of the R/V Nagasaki-maru, Nagasaki Univ., Mitsuru Hayashi and the Captain and crew of the R/V Fukae-maru Kobe Univ., Japan, Mr. Yamamoto and the Captain and crew of a ferry of Sado Kisen, Niigata, Japan, Akira Wada and the Captain and crew of Ferry Coral Queen Plus of Marix Line, Kagoshima, Japan, Kenichi Sasaki and the Captain and crew of the R/V Ushio-maru, Hokkaido Univ., Hakodate, Japan and Keiri Imai and the Captain and crew of the R/V Oshoro-maru, Hokkaido Univ., Hakodate, Japan, and Hirofumi Tazoe for his work to collect seawater samples onboard the R/V Hakuho-Maru, JAMSTEC, Japan. We also thank to Rika Hozumi for her work to extract radiocaesium from seawater samples, thank to Yukiko Suda for her work to treat spectrum data and thank to Tomomi Onda for her work to preparer tables and figures.

This work partially supported by Grant-in-Aid for Scientific Research on Innovative Areas, the Ministry of Education, Culture, Sports, Science and Technology Japan (KAKENHI), No. \#24110005.

\section{References}

[1] The-2011-Tohoku-Earthquake-Tsunami-JointSurvey-Group. Nationwide Field Survey of the 2011 Off the Pacific Coast of Tohoku Earthquake Tsunami, J. J. Soc.Civil Eng. , Ser B2 (Coastal Engineering). 67, (2011), pp. 63-66.

[2] P. P. Povinec, K. Hirose and M. Aoyama, Fukushima Accident: Radioactivity Impact on the Environment, Elsevier (2013), pp. 1-400.

[3] K. Buesseler, M. Aoyama and M. Fukasawa, Impacts of the Fukushima nuclear power plants on marine radioactivity, Environ. Sci. Technol. 45 (2011), pp. 9931-9935.

[4] K. Nishihara, H. Iwamoto and K. Suyama, Estimation of Fuel Compositions in Fukushima-Daiichi Nuclear Power Plant, JAEA-Data/Code 18 (2012), pp. 1-190.

[5] K. Buesseler, M. Dai, M. Aoyama, C. Benitez-Nelson, S. Charmasson, K. Higley, V. Maderich, P. Masque, P. J. Morris, D. Oughton and J. N. Smith, Fukushima Daiichi-Derived Radionuclides in the Ocean: Transport, Fate, and Impacts, Ann. Rev. Mar. Sci. 9 (2017), pp. 173-203.

[6] M. Kusakabe, S. Oikawa, H. Takata and J. Misonoo, Spatiotemporal distributions of Fukushima-derived radionuclides in nearby marine surface sediments, Biogeosciences 10 (2013), pp.5019-5030.

[7] E. E. Black and K. O. Buesseler, Spatial variability and the fate of cesium in coastal sediments near Fukushima, Japan, Biogeosciences 11 (2014), pp.5123-5137.

[8] D. Tsumune, T. Tsubono, M. Aoyama and K.
Hirose, Distribution of oceanic ${ }^{137} \mathrm{Cs}$ from the Fukushima Dai-ichi Nuclear Power Plant simulated numerically by a regional ocean model, J. Environ. Radioact. 11 (2012), pp. 100-108.

[9] M. Aoyama, M. Kajino, T.Y. Tanaka, T.T. Sekiyama, D. Tsumune, T. Tsubono, Y. Hamajima, Y. Inomata and T. Gamo, ${ }^{134} \mathrm{Cs}$ and ${ }^{137} \mathrm{Cs}$ in the North Pacific Ocean derived from the March 2011 TEPCO Fukushima Dai-ichi Nuclear Power Plant accident, Japan. Part two: estimation of ${ }^{134} \mathrm{Cs}$ and ${ }^{137} \mathrm{Cs}$ inventories in the North Pacific Ocean, $J$. Oceano. 72 (2016), pp. 67-76.

[10] Y. Inomata, M. Aoyama, T. Tsubono, D. Tsumune and K. Hirose, Spatial and temporal distributions of ${ }^{134} \mathrm{Cs}$ and ${ }^{137} \mathrm{Cs}$ derived from the TEPCO Fukushima Daiichi Nuclear Power Plant accident in the North Pacific Ocean by using optimal interpolation analysis, Environ. Sci. Processes \& Impacts 18 (2016), pp. 126-136.

[11] T. Tsubono, K. Misumi, D. Tsumune, F. O. Bryan, K. Hirose and M. Aoyama, Evaluation of radioactive cesium impact from atmospheric deposition and direct release fluxes into the North Pacific from the Fukushima Daiichi nuclear power plant, Deep Sea Res. Part I: Oceano. Res. Papers 115 (2016) pp. 10-21.

[12] H. Kaeriyama, Y. Shimizu, T. Setou, Y. Kumamoto, M. Okazaki, D. Ambe and T. Ono, Intrusion of Fukushima-derived radiocaesium into subsurface water due to formation of mode waters in the North Pacific, Sci. Rep. 6 (2016), pp. 22010 , DOI: $10.1038 /$ srep22010.

[13] A. Mathieu, I. Korsakissok, D. Quelo, J. Groell, M. Tombette, D. Didier, E. Quentric, O. Saunier, J.P. Benoit and O. Isnard, Atmospheric Dispersion and Deposition of Radionuclides from the Fukushima Daiichi Nuclear Power Plant Accident, Elements 8 (2012), pp. 195-200.

[14] V. Winiarek, M. Bocquet, N. Duhanyan, Y. Roustan, O. Saunier and A. Mathieu, Estimation of the caesium-137 source term from the Fukushima Daiichi nuclear power plant using a consistent joint assimilation of air concentration and deposition observations, Atmos. Environ. 82 (2014), pp. 268-279.

[15] O. Saunier, A. Mathieu, D. Didier, M. Tombette, D. Quélo, V. Winiarek and M. Bocquet, An inverse modeling method to assess the source term of the Fukushima nuclear power plant accident using gamma dose rate observations, Atmos. Chem. Phys. 13 (2013), pp. 11403-11421.

[16] G. Katata, M. Chino, T. Kobayashi, H. Terada, M. Ota, H. Nagai, M. Kajino, R. Draxler, M. Hort and A. Malo, Detailed source term estimation of the atmospheric release for the Fukushima Daiichi Nuclear Power Station accident by coupling simulations of an atmospheric dispersion model with an improved deposition scheme and oceanic dispersion model, Atmos. Chem. Phys. 15 (2015), pp. 1029-1070. 
[17] H. Kawamura, T. Kobayashi, A. Furuno, T. In, Y. Ishikawa, T. Nakayama, S. Shima and T. Awaji, Preliminary numerical experiments on oceanic dispersion of ${ }^{131} \mathrm{I}$ and ${ }^{137} \mathrm{Cs}$ discharged into the ocean because of the Fukushima Daiichi Nuclear Power Plant Disaster, J. Nucl. Sci. Technol. 48 (2011), pp. 1349-1356.

[18] C. Estournel, E. Bosc, M. Bocquet, C. Ulses, P. Marsaleix, V. Winiarek, I. Osvath, C. Nguyen, T. Duhaut, F. Lyard, H. Michaud and F. Auclair, Assessment of the amount of cesium-137 released into the Pacific Ocean after the Fukushima accident and analysis of its dispersion in Japanese coastal waters, J. Geophys. Res. 117 (2012), pp. C11014.

[19] Y. Miyazawa, Y. Masumoto, S. Varlamov, T. Miyama, M. Takigawa, M. Honda and T. Saino, Inverse estimation of source parameters of oceanic radioactivity dispersion models associated with the Fukushima accident, Biogeosciences 10 (2013), pp. 2349-2363.

[20] Y. Inomata, M. Aoyama, T. Tsubono, D. Tsumune and K. Hirose, Spatial and temporal distributions of ${ }^{134} \mathrm{Cs}$ and ${ }^{137} \mathrm{Cs}$ derived from the TEPCO Fukushima Daiichi Nuclear Power Plant accident in the North Pacific Ocean by using optimal interpolation analysis, Environ. Sci.: Processes \& Impacts 18 (2016), pp.126-136.

[21] M. Aoyama and K. Hirose, Radiometric determination of anthropogenic radionuclides in seawater. In Radiometric Determination of Anthropogenic Radionuclides in Seawater, (Ed. P.P. Pavel), Elsevier, Hungary, (2008), pp.137-162.

[22] Y. Hamajima and K. Komura, Background components of Ge detectors in Ogoya underground laboratory, Appl. Radiat. Isot. 61 (2004), pp.179-183.

[23] M. Aoyama, Guidline of Ocean Observations 9 Natural and Artificial Radioactivity, The Oceanographic Society of Japan, Tokyo, (2018), pp. G901EN:001-013.

[24] D. Tsumune, M. Aoyama, K. Hirose, F. O. Bryan, K. Lindsay and G. Danabasoglu, Transport of ${ }^{137} \mathrm{Cs}$ to the Southern Hemisphere in an ocean general circulation model, Prog. In Oceanog. 89 (2011), pp.38-48.

[25] D. Tsumune, T. Tsubono, M. Aoyama, M. Uematsu, K. Misumi, Y. Maeda, Y. Yoshida and H. Hayami, One-year, regional-scale simulation of $137 \mathrm{Cs}$ radioactivity in the ocean following the Fukushima Daiichi Nuclear Power Plant accident, Biogeosciences 10 (2013), pp.5601-5617.

[26] M. Aoyama, D. Tsumune, M. Uematsu, F. Kondo and Y. Hamajima, Temporal variation of ${ }^{134} \mathrm{Cs}$ and ${ }^{137} \mathrm{Cs}$ activities in surface water at stations along the coastline near the Fukushima Dai-ichi Nuclear Power Plant accident site, Japan, Geochem. J. 46 (2012), pp.321-325.

[27] M. Aoyama, Y. Hamajima, M. Hult, M. Uematsu, E. Oka, D. Tsumune and Y. Kumamoto, ${ }^{134} \mathrm{Cs}$ and ${ }^{137} \mathrm{Cs}$ in the North Pacific Ocean derived from the March 2011 TEPCO Fukushima Dai-ichi Nuclear Power Plant accident, Japan. Part one: surface pathway and vertical distributions, J. Oceanogr. 72 (2016), pp.53-65.

[28] M. Aoyama, Y. Hamajima, Y. Inomata and E. Oka, Recirculation of FNPP1-derived radiocaesium observed in winter 2015/2016 in coastal regions of Japan, Appl. Radiat.Isot. 126 (2017), pp.83-87.

[29] Y. Kumamoto, M. Aoyama, Y. Hamajima, S. Nishino, A. Murata and T. Kikuchi, Meridional distribution of Fukushima-derived radiocesium in surface seawater along a trans-Pacific line from the Arctic to Antarctic Oceans in summer 2012, J. Radioanal. and Nucl. Chem. 307 (2016), pp.1703-1710.

[30] M. Aoyama, M. Uematsu, D. Tsumune and Y. Hamajima, Surface pathway of radioactive plume of TEPCO Fukushima NPP1 released ${ }^{134} \mathrm{Cs}$ and ${ }^{137}$ Cs. Biogeosciences 10 (2013), pp.3067-3078.

[31] Y. Kumamoto, M. Aoyama, Y. Hamajima, T. Aono, S. Kouketsu, A. Murata and T. Kawano, Southward spreading of the Fukushima-derived radiocesium across the Kuroshio Extension in the North Pacific, Sci. Rep. 4 (2014), pp.4276, DOI:10.1038/srep04276. 